ACTA AGROBOTANICA

Vol. 67 (4), 2014: 3-12

Original Research Paper

DOI: 10.5586/aa.2014.054

\title{
MICROMORPHOLOGY AND ANATOMY OF FLOWERS AND NECTARIES OF Saxifraga stolonifera $\mathrm{L}$.
}

\author{
Agata Konarska \\ Department of Botany, University of Life Sciences in Lublin \\ Akademicka 15, 20-950 Lublin, Poland \\ agata.konarska@up.lublin.pl
}

Received: 13.08.2014

\begin{abstract}
Saxifrages are plants commonly found in all continents. Many of them are adapted to flowering and reproduction under mountainous and rocky conditions. They are pollinated by various groups of insects and have intrastaminal nectaries. The morpho-anatomy of the flowers and nectaries of Saxifraga stolonifera L. was examined using bright-field light and stereoscopic microscopy as well as scanning electron microscopy. The abaxial surface of the sepals has multicellular glandular trichomes containing anthocyanins in the base cells and polyphenols in the secretory cells of the head, whereas visual attractants in the form of color spots are found on the petals. The nectary gland is located at the apex of the ovary and forms a yellow-orange fleshy half-ring. Nectar is secreted through numerous modified stomata. The glandular parenchyma does not have vascular elements. Moreover, orange-brown polyphenols were observed in the nectary cells.
\end{abstract}

Key words: strawberry saxifrage; nectar guides; nectary structure; trichomes; poliphenols

\section{INTRODUCTION}

The Saxifragaceae family includes 540 species, out of which various Saxifraga species account for more than $80 \%$. Saxifrages are cushion or mat-forming perennials which are distributed in the subarctic and arctic zones of the Northern Hemisphere, inhabiting primarily higher mountain belts, as well as in the mountains of North Africa and South America. But some of them also occur in the tropical zone. Saxifrage species are significantly varied ecologically, though many of them show adaptations to mountainous, stony or rocky habitats $[1,2]$. In Poland 18 Saxifraga species are found in the wild, while about 150 species are cultivated $[3,4]$. The cultivated species are divided into 16 sections, depending on the properties and requirements, but most of them belong to the sections Euaizoonia, Dactyloides, Kabschia, and Engleria [1]. Pollinators for the flowers of Saxifragaceae are mainly flies, especially of the families Empididae and Syrphidae, but also honey and solitary bees, bumblebees, butterflies, ants, and beetles [5-8]. Intrastaminal and annular nectaries, located on the receptacle between the base of the stamens and the ovary, usually occur in the flowers of Saxifragaceae [9-12], but gynoecial nectaries can also be found [13]. The nectaries are most frequently composed of yellow, green or green-yellow glandular tissue and nectar is secreted just before the stigmata become receptive [6]. Nectar contains predominantly fructose and glucose, whereas sucrose occurs rarely $[14,15]$.

Strawberry saxifrage (Saxifraga stolonifera L.), native to China and Japan, is a perennial belonging to the section Kabschia - Engleria and is called "Mother of Thousands" due to daughter plants produced in large numbers at the end of stolons [1]. In Poland this species is primarily grown as an ornamental pot plant, whereas in warmer climate countries, but also in Poland's warmer regions, it can also be found in rock gardens as a popular ground cover plant [16].

Many authors think that the location and structure of flower nectaries as well as the mechanism of nectar secretion can elucidate the origin and evolution of various plant groups and provide important taxonomic significance $[12,14,17-20]$. Because little information was found about the function and structure of floral nectaries in Saxifraga species, which are relatively common representatives of the flora of all the continents, the aim of the present study was to show 
the structure of floral nectaries in S. stolonifera at the micromorphological and anatomical level. Furthermore, in order to complement the knowledge on the flower morphology in the genus Saxifraga, some morphological traits of these organs in S. stolonifera were characterized quantitatively and qualitatively.

\section{MATERIALS AND METHODS}

Saxifraga stolonifera L. flowers at anthesis and peak nectar secretion were collected in the middle of June 2013 from plants grown in pots indoors (temp. about $20^{\circ} \mathrm{C}$ ). The structure of floral nectaries and the micromorphology of strawberry saxifrage flowers were observed using bright-field light microscopy (LM) and stereoscopic microscopy (SLM) as well as scanning electron microscopy (SEM).

For SEM, flowers with nectary disc were fixed in $4 \%$ glutaraldehyde in $0.1 \mathrm{M}$ phosphate buffer with a $\mathrm{pH}$ of 7.0. Next, the samples were dehydrated in an ethanol series and dried at the critical point in liquid $\mathrm{CO}_{2}$ (Bal-Tec CPD 030 critical point dryer) and coated with gold-palladium using the sputter coater EMITECH K 550x. The preparations were observed under a TESCAN/VEGA LMU scanning electron microscope at an accelerating voltage of $30 \mathrm{kV}$. The length of glandular trichomes occurring on the sepals and nectaries nectarostomata (guard cells) $(n=20)$ were measured and the number of stomata per $\mathrm{mm}^{2}$ of the nectary epidermis area was counted $(n=5)$.

The diameter (along the longest diagonal) of 10 flowers was determined under a stereoscopic microscope and the size of the following individual flower parts were measured: width and length of sepals and petals $(n=25)$, width and length of the stamen filaments and anthers, $(\mathrm{n}=50)$, width and length of the pistil styles (at the base) $(\mathrm{n}=20)$ and the pistil diameter with a nectary $(n=10)$. Moreover, the values of the parameters characterizing the floral nectaries $(n=10)$ were determined: width and length of the nectary (top and lateral view), height of the nectary (lateral view), distance from the inner wall of the nectary to the pistil styles (top view), length of the higher and of the lower nectary outgrowths.

Glycerol-mounted slides were prepared from the ovary with a nectary. Longitudinal and transverse sections were cut by hand with a razor blade. Under a Nikon SE 102 light microscope thickness of the ovary walls, height of the epidermal cells and thickness of the nectary tissue were measured, as well as the number of the nectariferous parenchyma layers was counted $(n=10)$. Subsequently, the sections were stained with $\mathrm{FeCl}_{3}$ to detect phenolic compounds [21] in the tissues of the nectary and ovary. For all measured parameters the means and standard deviations $( \pm \mathrm{SD})$ were calculated.

\section{RESULTS}

Saxifraga stolonifera produces basal, longpetiolate, hairy leaves forming wide-spreading leaf rosettes. Small flowers appear from May to August and are borne in cymose inflorescences. The protandrous flowers of S. stolonifera are asymmetrical and the petals are white-pink colored (Fig. 1a). Two white petals, almost four times longer than the other ones, are pointed downwards. Three shorter petals, pointed upwards, have a similar size and are characterized by partially pink color and the presence of flavonoid pigments producing contrasting yellow spots at the base of the petals (Table 1, Fig. 1a,b). The epidermal cells of the petals produced papillae, i.e. characteristic outgrowths that give a special sheen to the petals (Fig. 1c,d). 5 green sepals, with claret veining running parallel to the longer axis of the sepal, were shorter by more than $60 \%$ and narrower by $24 \%$ than the smaller petals (Table 1 , Fig. 1e). On the abaxial side, the sepals were covered by epidermal cells which generally had convex outer walls that produced peltate glandular trichomes, particularly numerous on the edge of the sepals (Fig. 1e-i). The trichomes had a very similar length and consisted of one basal cell, 4-5 stalk cells containing anthocyanins, and a multicellular head with a height that accounted for about $20 \%$ of the total trichome length (Table 1, Fig. 1g-i). The trichome head consisted of 2 or 3 tiers of cells, with 4 secretory cells in each tier. The secretion present in the secretory cells of the trichome heads and observed in the form of droplets at their top contained polyphenols staining brown-green with $\mathrm{FeCl}_{3}$ (not shown). Oval projections covered by epidermis with smaller cells, on which clusters of stomata were located, were also noticed on the abaxial side of the sepals (Fig. 1f,j). The stomata also occurred outside these projections, but at a lower density.

The generative organs in strawberry saxifrage flowers also include the superior pistil with two free styles narrowing in the direction of the stigma and 10 stamens with a similar length, arranged alternately to the petals, which were characterized by white stamen filaments and pink anthers (Table 1, Fig. 1a,b). The surface of the pistil styles was composed of prosenchymatous epidermal cells covered by a smooth cuticle, whereas numerous elongated papillae were found on the stigmas (Fig. 2a). The yellow-orange nectary gland, in the shape of a half-ring with two walls limiting this half-ring and terminating in characteristic outgrowths ("teeth"), was located at the apex of the ovary (Table 1, Fig. 1a, Fig. 2b-g). A wavy cavity, with several depressions, was formed between the walls limiting the nectary (Fig. $2 \mathrm{e}, \mathrm{g})$. The outer wall of the gland had 6 outgrowths, whereas the inner wall, closer to the styles, had more numerous outgrowths but lower by about $40 \%$ compared to those present on the outer wall (Table 1, Fig. 2e-g). 
The surface of both types of outgrowths was composed of epidermis with densely packed cells with a regular hexagonal outline and convex outer walls covered by slightly striated cuticle (Fig. 3a,b). Nectar was secreted by numerous modified, frequently raised stomata located in particular in the epidermis of the nectary cavity and in the lower parts of the outgrowths from the side of the depression (Table 1, Fig. 3c-g). Initially, the nectar accumulated in the depressions of the nectary cavity, but after they had been filled up, it seeped through to two large depressions located between the inner wall of the gland and the base of the styles (Fig. 2b,e,g, Fig. 3c).

In the cross sections of the ovary with the nectary, it was observed that the nectary gland was com- posed of a single-layered epidermis, whose cells were characterized by greater height than the width and which generally had the orange-brown color of living protoplasts, and 5-10 layers of glandular parenchyma adjacent to the ovary wall (Table 1, Fig. $4 a-c$ ). No vascular elements were observed in the glandular parenchyma. On the other hand, polyphenols were found in some glandular parenchyma cells as well as in the wall cells of the ovary, placenta, and ovules, and they gave the orange-brown color to the cells of the abovementioned organs (Fig. 4a-c). The presence of phenolic compounds was confirmed by the reaction with $\mathrm{FeCl}_{3}$ which stained the deposits of these compounds orange-green.

Table 1

The characteristics of Saxifraga stolonifera flowers and nectaries

\begin{tabular}{|c|c|c|}
\hline Flower & Diameter & $14.75 \pm 1.2 \mathrm{~mm}$ \\
\hline \multirow{4}{*}{ Petal } & Length of the large petals & $9.33 \pm 1.0 \mathrm{~mm}$ \\
\hline & Length of the small petals & $2.48 \pm 0.5 \mathrm{~mm}$ \\
\hline & Width of the large petals & $1.89 \pm 0.3 \mathrm{~mm}$ \\
\hline & Width of the small petals & $1.83 \pm 0.2 \mathrm{~mm}$ \\
\hline \multirow{5}{*}{ Sepal } & Length of sepals & $1.58 \pm 0.1 \mathrm{~mm}$ \\
\hline & Width of sepals & $1.39 \pm 0.2 \mathrm{~mm}$ \\
\hline & Lenght of the glandular trichomes & $182.2 \pm 10.5 \mu \mathrm{m}$ \\
\hline & Height of the trichome heads & $37.8 \pm 3.5 \mu \mathrm{m}$ \\
\hline & Lenght of the trichome stalks & $123.38 \pm 6.6 \mu \mathrm{m}$ \\
\hline \multirow{5}{*}{ Stamen } & Length of stamens & $3.37 \pm 0.3 \mathrm{~mm}$ \\
\hline & Length of anthers & $495.25 \pm 6.2 \mu \mathrm{m}$ \\
\hline & Length of filaments & $1.78 \pm 0.5 \mathrm{~mm}$ \\
\hline & Width of anthers & $908 \pm 35.5 \mu \mathrm{m}$ \\
\hline & Width of filaments & $434.5 \pm 38.4 \mu \mathrm{m}$ \\
\hline \multirow{4}{*}{ Pistil } & Length of styles & $2.69 \pm 0.4 \mathrm{~mm}$ \\
\hline & Diameter of the basal part of the styles & $729.35 \pm 85.1 \mu \mathrm{m}$ \\
\hline & Diameter of the ovaries with nectaries & $1.96 \pm 0.2 \times 2.64 \pm 0.1 \mathrm{~mm}$ \\
\hline & Thickness of the ovary walls & $81.85 \pm 2.2 \mu \mathrm{m}$ \\
\hline \multirow{12}{*}{ Nectary } & Width of nectaries (top view) & $495.47 \pm 72.4 \mu \mathrm{m}$ \\
\hline & Length of nectaries (lateral view) & $2.46 \pm 0.3 \mathrm{~mm}$ \\
\hline & Height of nectaries (lateral view) & $2.21 \pm 0.2 \mathrm{~mm}$ \\
\hline & $\begin{array}{l}\text { Distance from the inner walls of the nectaries to the pistil styles } \\
\text { (top view) }\end{array}$ & $513.15 \pm 80.1 \mu \mathrm{m}$ \\
\hline & Lenght of the higher nectary outgrowths & $394.75 \pm 43.6 \mu \mathrm{m}$ \\
\hline & Lenght of the lower nectary outgrowths & $236.85 \pm 35.2 \mu \mathrm{m}$ \\
\hline & Number of stomata per $\mathrm{mm}^{2}$ of nectary area & $118 \pm 3$ \\
\hline & Lenght of stomata & $21.98 \pm 5.3 \mu \mathrm{m}$ \\
\hline & Width of stomata & $18.22 \pm 3.2 \mu \mathrm{m}$ \\
\hline & Thickness of the nectary tissue & $235.84 \pm 28.7 \mu \mathrm{m}$ \\
\hline & Number of the secretory parenchyma layers & $5-10(8) \pm 2$ \\
\hline & Height of the nectar epidermis cells & $23.79 \pm 6.2 \mu \mathrm{m}$ \\
\hline
\end{tabular}



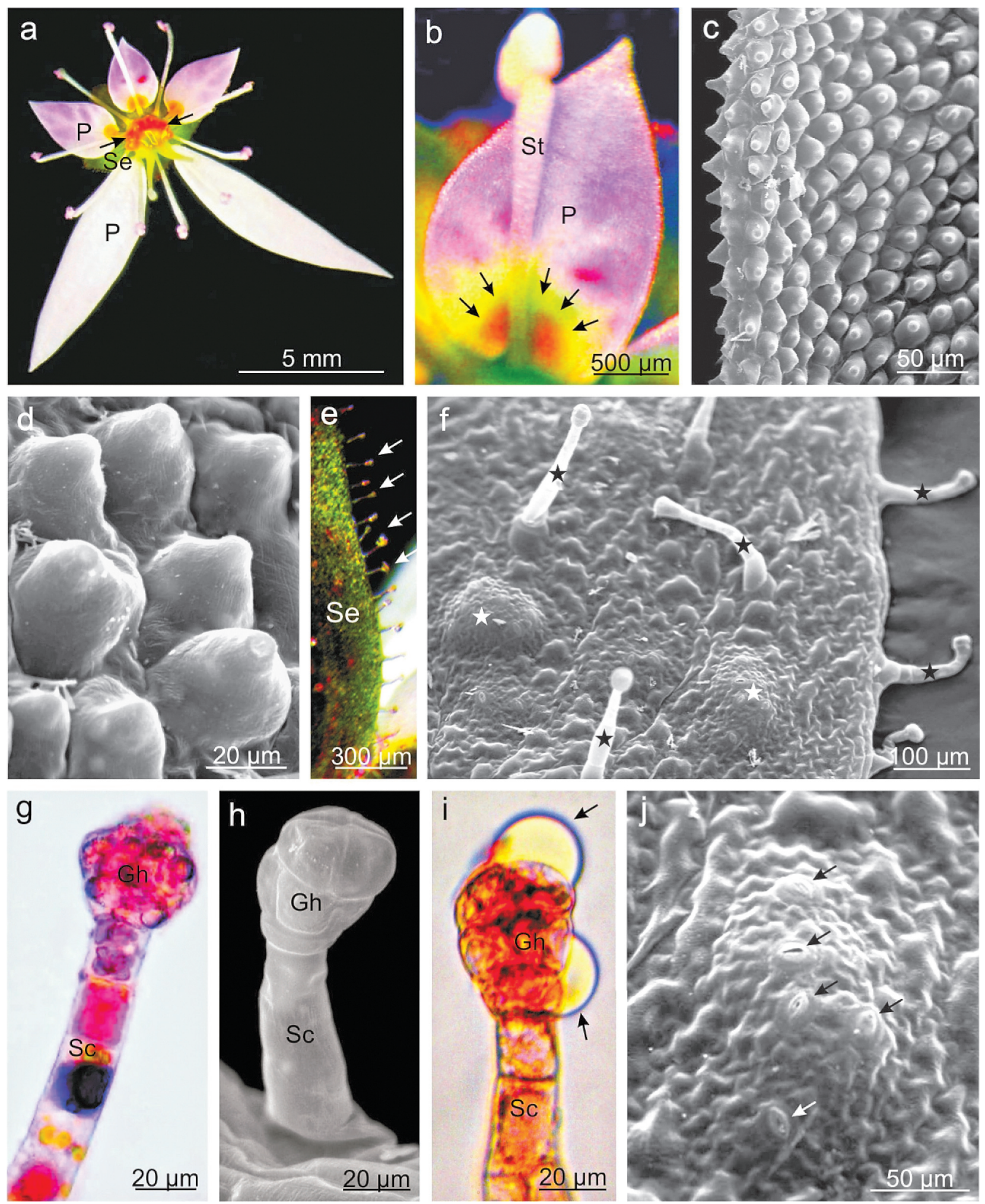

Fig. 1. Details of Saxifraga stolonifera flowers. a Flower with a yellow-orange nectary (arrows). b Visible yellow and contrasting spots (nectar guides) at the base of the petal (arrows). c Petal surface with papillae. $\mathbf{d}$ Papillae on the petal surface. e Fragment of the sepal with peltate glandular trichomes (arrows). f Surface of the abaxial side of the sepal with glandular trichomes (black asterisks) and depressions with stomata (white asterisks). g-i Glandular trichomes with anthocyanins in stalk cells (g), and with secretion drops (arrows) (i). j On the sepal visible a depression with stomata (arrows). P - petal; Se - sepal; St stamen; Gh - glandular head; Sc - stalk cell. 

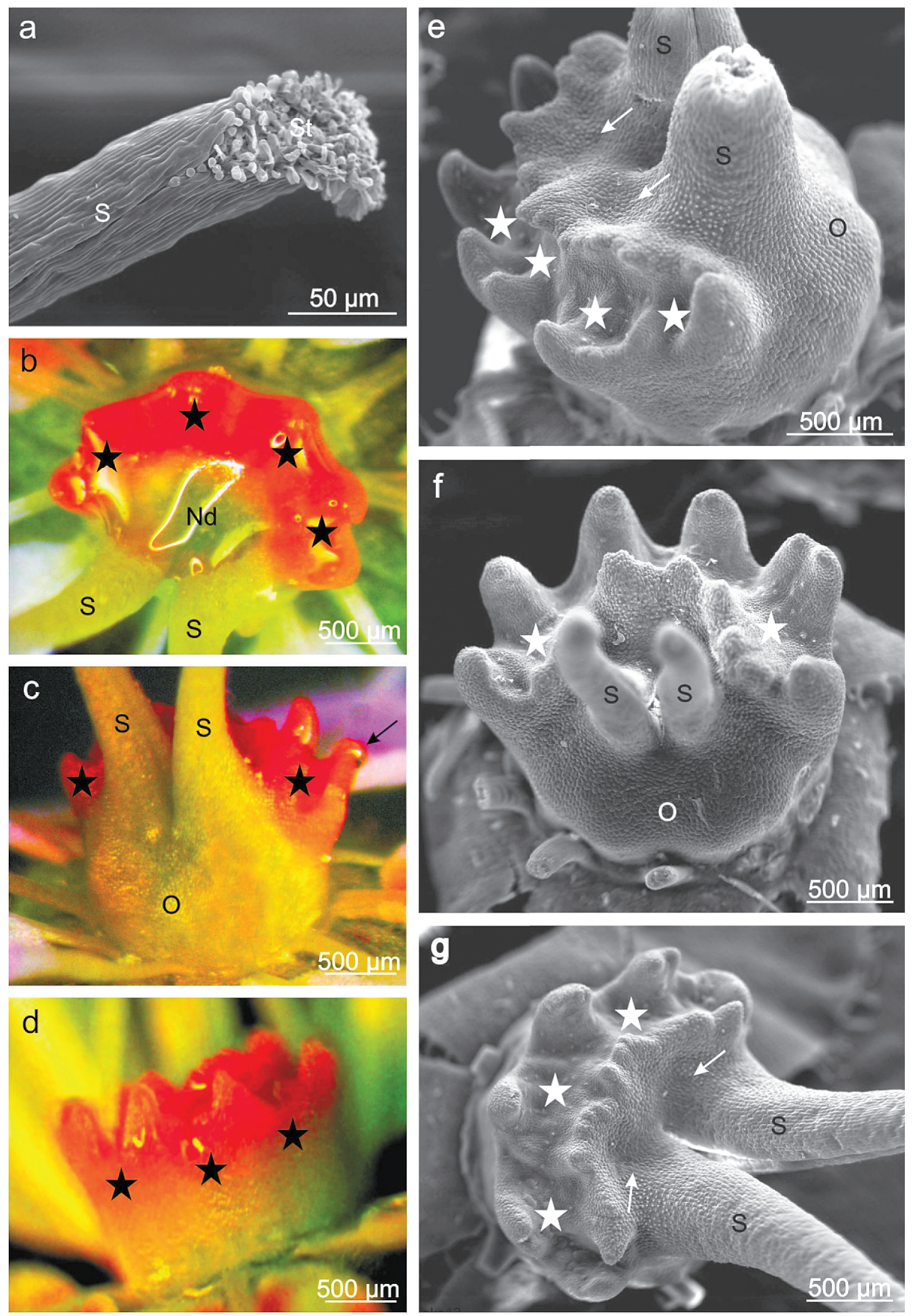

Fig. 2. Pistil and ovaries with nectaries in S. stolonifera. a Fragment of the style with a stigma formed with numerous papillae. b-g Half-ring nectary disc with characteristics tooth-shaped appendages; b-d SM. b Visible a drop of nectar (Nd) in the nectary cavity (top view). c Note a drop of nectar on the nectary appendages (arrow) (lateral view). e-g SEM. Visible the cavity of the nectary (asterisks) between two walls of the gland and depressions between the nectary and the styles of the pistil (arrows) where the nectar was accumulated. $\mathrm{O}$ - ovary; $\mathrm{S}$ - style; $\mathrm{St}$ - stigma. 

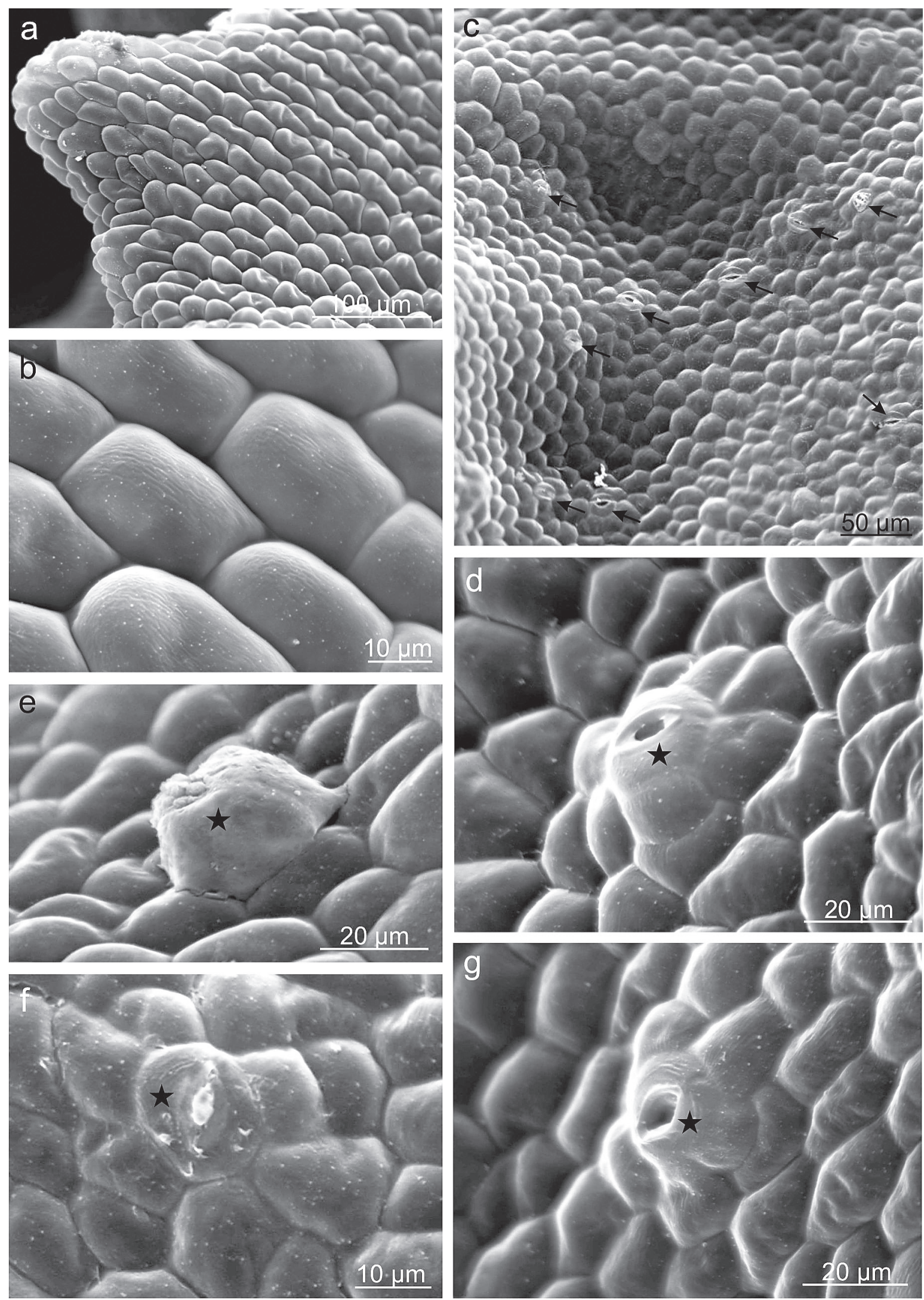

Fig. 3. Surface of the S. stolonifera nectaries with nectarostomata. a,b Epidermal cells of the nectary appendages. $\mathbf{c}$ The nectary cavities with numerous nectarostomata (arrows). d-g Visible nectarostomata (asterisks) located on the convexities (d,g), covered with secretions (e) or with secretion in stomata pores (f). 

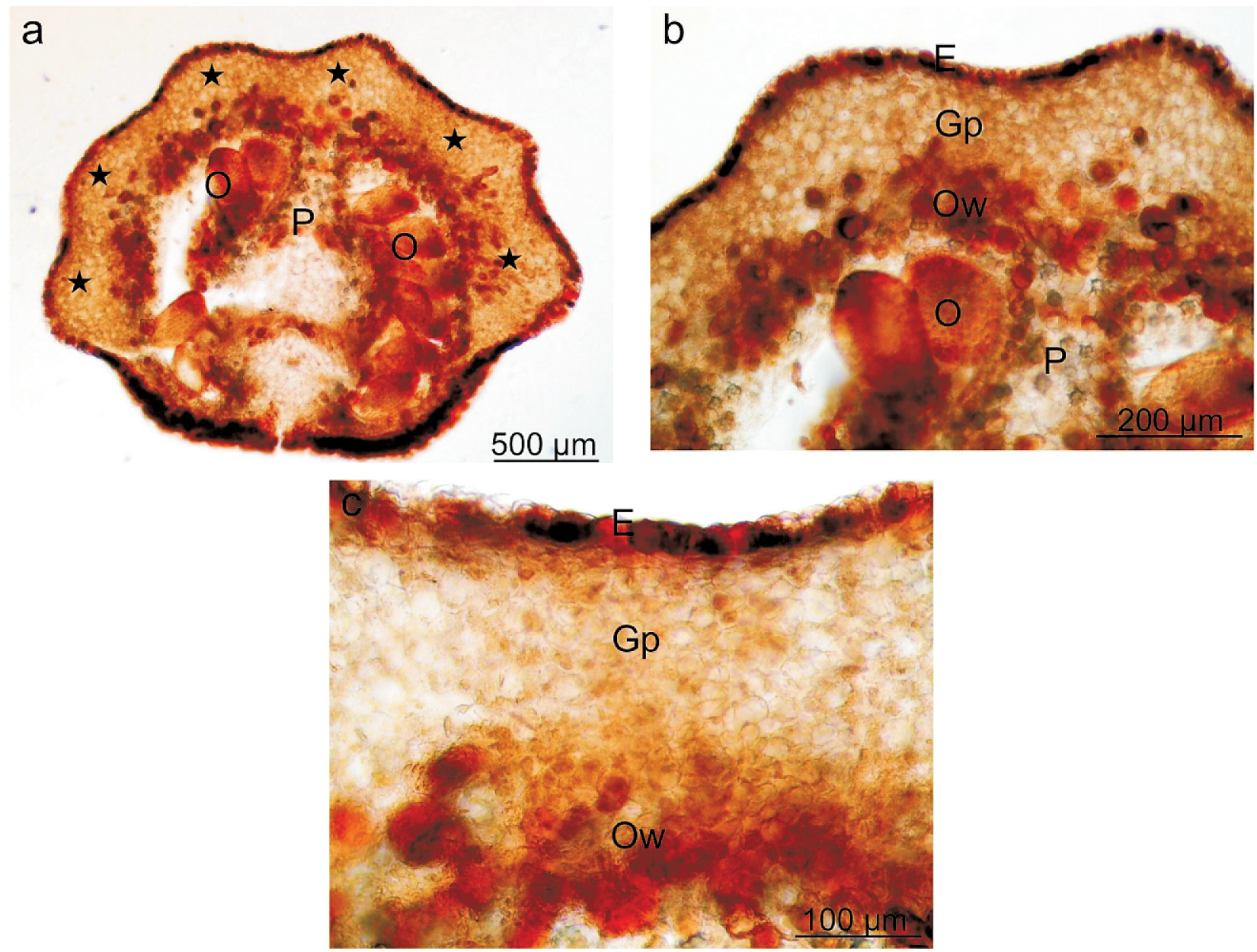

Fig. 4. Anatomy of S. stolonifera nectaries. a,b Cross-sections of the ovary with the nectary (asterisks). Note dark stained epidermal cells of the nectary and ovary walls containing polyphenols. c Cross section across the nectariferous tissue. Note browncolored cells of the nectary epidermis and ovary walls containing polyphenols. O - ovules; P - placenta; E - epidermis; Gp - glandular parenchyma; Ow - ovary wall.

\section{DISCUSSION}

In Saxifraga stolonifera, similarly to the leaf blades and stalks, the sepals were covered with numerous multiseriate glandular trichomes containing anthocyanins in the base cells and polyphenols in the cells of the heads, probably tannins. Numerous authors report that many representatives of the family Saxifragaceae are generally more or less hairy, often glandular $[5,6,22,23]$. G o r n a 11 [24] observed in various Saxifraga species as many as 6 trichome types: i) multiseriate glandular, ii) uniseriate, glandular, iii) sessile, multicelular, glandular, iv) multiseriate, eglandular, v) uniseriate, eglandular and vi) unicellular, eglandular. Moreover, epidermal glandular hairs that contained tannin-like substances in the head cells were also observed by B e n s e 1 and P a 1 s e r [10] in Tiarella cordifolia (Saxifragaceae). In S. stolonifera, dark stained cells containing polyphenols were also observed in the epidermis and in the glandular tissue of the nectaries as well as in the cells of the ovary, placenta, and ovules. Phenolic compounds in the form of dark-staining, most frequently tannin-like substances in the nectaries of different plant species have been described by other researchers [25-29]. According to Barbehenn \& Constabel [30] and Salminen \& Karonen [31], tannins provide protection against predation from herbivorous animals and pathogenic attack from bacteria and fungi. The presence of polyphenolic and other secondary compounds in nectary cells deter nectar-infecting microorganisms and foraging insects but sometimes also insect pollinators [32]. J a w orska and $\mathrm{N}$ y b o m [33] report that in Saxifraga about 50 various phenols were detected, predominantly tannins. Many of them have medicinal properties [34,35]; S. stolonifera stems were used as an herbal remedy in Classical Japan for many different ailments. It contains quercetin which has been shown to have anti-cancer activity $[36,37]$.

The asymmetrical flowers of $S$. stolonifera are characterized by pink anthers and a varied distribution 
of yellow and pink flavonoid pigments in the petals, forming on the petals contrasting spots, the so-called nectar guides which show the way to the nectar to pollinating insects. Similarly as in S. stolonifera, patterns of red, orange or yellow are found on the delicately spotted petals of S. tricuspidata and S. hirculus [37]. Olesen and Warncke [7] think that flavonoids coloring the petals of $S$. hirculus in yellow reflected ultrafiolet and yellow light making them insect-purple. According to Ke van [37], yellow flowers are the most attractive to insects, whereas white flowers which reflect little or no ultrafiolet are the least attractive. Moreover, flowers appearing white and pink to humans (as S. stolonifera) are mostly blue-green for bees and other trichromatic insects [38], whereas yellow flowers can be green or UV-green, depending on their UV reflectance, to such insects [39]. E1 v a n d e r [5] also draws attention to the contrasting color of anthers in other Saxifraga species; by taking on the yellow or orange color, the anthers additionally attract pollinating insects.

The nectary gland in the flowers of S. stolonifera was located at the top of the ovary, forming a characteristic half-ring between the styles of the pistil and the bases of the stamen filaments. Various authors report that in other Saxifraga species the open nectaries are inconspicuous and can be disc-like, ribbon-like or obscure, or they can be absent completely [5,8,10,22]. According to many studies, $[9,11,12,15]$ nectaries in Saxifragaceae occur most frequently on the receptacle or on the ovary and they are generally intrastaminal and annular nectaries. Decraene et al. [13] described the location of nectary tissue in the gynoecium (as its part) in Chrysosplenium alternifolium, which untypical for representatives of Saxifragaceae. In turn, $\mathrm{B}$ e n s e 1 and Pals er [10] found that in many Saxifragaceae species the nectariferous tissue usually covers the abaxial surfaces of the pistils and frequently extends some distance up the adaxial surface of the floral cup. O le se $\mathrm{n}$ and $\mathrm{W}$ a r n cke [7] and Lindga ard Hansen and Molau [8] report, however, that flowers of various Saxifraga species produce relatively small amounts of nectar, but despite that they are attractive to pollinating insects and visited by them in great numbers.

The nectar in the flowers of S. stolonifera was secreted through modified nectarostomata. In the available literature on the development and structure of floral nectaries in various representatives of Saxifragaceae, no information was found on the mechanism of nectar secretion. Nevertheless, a similar location of the nectaries and nectar secretion through modified stomata was described by W e i g e n d [40] in the family Grossulariaceae, closely related to Saxifragaceae.
According to this author, the nectaries in Grossulariaceae are very strongly developed and form an extensive disc or cup. The author of present paper found that the secretory parenchyma in the nectaries of $S$. stolonifera did not have vascular tissue. With such a small size of the nectaries, they were probably supplied with assimilates and water through the vascular bundles of the perianth segments or ovary.

\section{CONCLUSIONS}

1. Polyphenols present in the secretion of glandular trichomes and in the cells of the nectary and ovary in S. stolonifera can be a protection against herbivores as well as fungal and bacterial microorganisms.

2. The presence of color spots on the petals and easily accessible floral nectaries in S. stolonifera are traits that promote insect pollination of these plants.

3. The location of floral nectaries in S. stolonifera is a characteristic typical for representatives of the family Saxifragaceae, but the micro-morphology of the floral nectaries and the mode of nectar secretion in this family were characterized for the first time.

\section{Acknowledgments}

This research was supported by the Ministry of Science and Higher Education of Poland as a part of the activities of the Department of Botany, University of Life Sciences in Lublin.

\section{REFERENCES}

1. R oy H, editor. Reader`s Digest encyclopedia of garden plants and flowers. London: The Reader`s Digest Association Limited; 1987.

2. Chmiel H. Uprawa roślin ozdobnych. Warszawa: PWRiL; 2000.

3. Szweykowska A, Szweykowski J. Słownik botaniczny. Warszawa: Państwowe Wydawnictwo Wiedza Powszechna; 2003.

4. Röth J. Pflanzez fürs Zimmer. Leipzig: Neuman Verlag; 1989.

5. Elvander P. The taxonomy of Saxifraga (Saxifragaceae) section Boraphila subsection Integrifoliae in western North America. Syst Bot Monogr. 1984; 3: 1-44. http://dx.doi. org/10.2307/25027593

6. Gornall R J, B ohm B A. A monograph of Boykinia, Peltoboykinia, Bolandra and Suksdorfia (Saxifragaceae). Bot J Linn Soc. 1985; 90(1): 1-71. http://dx.doi.org/10. 1111/j.1095-8339.1985.tb02201.x

7. Olesen JM, Warncke E. Flowering and seasonal changes in flower sex ratio and frequency of flower visitors in a population of Saxifraga hirculus. Ecography. 1989; 12(1): 21-30. 
8. Lindgaard Hansen JE, Molau U. Pollination biology, mating system, and seed set in a Danish population of Saxifraga granulata. Nordic J Bot. 1994; 14(3): 257-268. http://dx.doi.org/10.1111/j.1756-1051.1994.tb00 597.x

9. Bense1, CR, Palser BF. Floral anatomy in the Saxifragaceae sensu lato. I. Introduction, Parnassioideae and Brexioideae. Am J Bot. 1975; 62(2): 176-185. http://dx.doi. org/10.2307/2441593

10. Bensel CR, Palser BF. Floral anatomy in the Saxifragaceae sensu lato. II. Saxifragoideae and Iteoideae. Am J Bot. 1975; 62(2): 661-675. http://dx.doi.org/ $10.2307 / 2441593$

11. Cronquist A. An integrated system of classification of flowering plants. 2nd ed. New York, NY: Columbia University Press; 1981.

12. S m e t s EF. Localization and systematic importance of the floral nectaries in the Magnoliatae (Dicotyledons). Bull Jard Bot Nat Belg. 1986; 56: 51-76.

13. Decraene LR, Roels P, Smets EF, Backlund A. The floral development and floral anatomy of Chrysosplenium alternifolium, an unusal member of the Saxifragaceae. J Plant Res. 1998; 111(4): 573-580.

14. Percival MS. Types of nectar in Angiosperms. New Phytol. 1961; 60: 242-247. http://dx.doi.org/10.11 11/j.1469-8137.1961.tb06255.x

15. Bernardello G, Galetto L, Anderson GJ. Floral nectary structure and nectar chemical composition of some species from Robinson Crusoe Island (Chile). Can J Bot. 2000; 78(7): 862-871. http://dx.doi.org/10.1139/ b00-055

16. L ong ma n D. The care of house plants. London: Wiliam Clowes \& Sons Ltd; 1979.

17. B a ker H, B a ker I. A brief historical review of the chemistry of floral nectar. In: Bentley B, Elias T, editors. The biology of nectaries. New York, NY: Columbia University Press; 1983. p. 126-152.

18. Endres s PK. Major evolutionary traits of monocot flowers. In: Rudall PJ, Cribb PJ, Cutler DF, Humphries CJ, editors. Monocotyledons: systematics and evolution. Kew: Royal Botanic Gardens; 1995: 43-79.

19. Rudall PJ, Manning JC, Goldblatt P. Evolution of floral nectaries in Iridaceae. Ann Miss Bot Gard. 2003; 90: 613-631.

20. B ernardello G. A systematic survey of floral nectaries. In: Nicolson SW, Nepi M, Pacini E, editors. Nectaries and Nectar. The Netherlands: Springer, Dordrecht; 2007. p. 19-128.

21. Johansen DA. Plant microtechnique. New York, NY: McGraw-Hill; 1940.

22. Elvander P. Saxifragaceae: saxifrage family. Journal Arizona-Nevada Academy of Science. 1992; 26(1): 36-41.

23. A $1-$ Shammar, KIA, Gornall R J. Trichome anatomy of the Saxifragaceae sl from the southern hemisphere. Bot J Linn Soc. 1994; 114(2): 99-131. http://dx.doi.org/ 10.1111/j.1095-8339.1994.tb01926.x
24. Gornall RJ. Trichome anatomy and taxonomy of Saxifraga (Saxifragaceae). Nord J Bot. 1986; 6(3): 257-275. http://dx.doi.org/10.1111/j.1756-1051.1986.tb00877.x

25. Beardsell DV, Williams EG, Knox RB. The structure and histochemistry of the nectary and anther secretory tissue of the flowers of Thryptomene calycina (Lindl) Stapf (Myrtaceae). Aust J Bot. 1989; 37: 65-80. http:// dx.doi.org/10.1071/BT9890065

26. Kon arska A. Comparison of the structure of floral nectaries in two Euonymus L. species (Celastraceae). Protoplasma. 2014 (in press). http://dx.doi.org/10.1007/s00709-01 4-0729-6

27. Matthews ML, Endress PK. Comparative floral structure and systematics in Celastrales (Celastraceae, Parnassiaceae, Lepidobotryaceae). Bot J Linn Soc. 2005; 149: 129-194. http://dx.doi.org/10.1111/j.1095-83 39.2005.00445.x

28. de-Paula OC, das Graças Sajo M, Prenner G, Cordeiro I, Rudall PJ. Morphology, development and homologies of the perianth and floral nectaries in Croton and Astraea (Euphorbiaceae-Malpighiales). Plant Syst Evol. 2011; 292: 1-14.

29. Montenegro G, Díaz-Forestier J, Fredes C, Rodríguez S. Phenolic profiles of nectar and honey of Quillaja saponaria Mol.(Quillajaceae) as potential chemical markers. Biol Res. 2013; 46: 177-182. http://dx.doi. org/10.4067/S0716-97602013000200009

30. B arbehenn RV, Constabel PC. Tannins in plantherbivore interactions. Phytochemistry. 2011; 72(13): 15511565. http://dx.doi.org/10.1016/j.phytochem.2011.01.040

31. Salminen JP, Karonen M. Chemical ecology of tannins and other phenolics: we need a change in approach. Funct Ecol. 2011; 25(2): 325-338. 10.1111/j.1365-2435. 2010.01826.x

32. Heil M. Nectar: generation, regulation and ecological functions. Trends Plant Sci. 2011; 16: 191-200. http://dx.doi. org/10.1016/j.tplants.2011.01.003

33. Jaworska H, Nybom N. A thin-layer chromatographic study of Saxifraga caesia, S. aizoides, and their putative hybrid. Hereditas. 1967; 57(1-2): 159-177. http://dx.doi. org/10.1111/j.1601-5223.1967.tb02098.x

34. Taneyama M, Yoshida S, Kobayashi M, $\mathrm{H}$ as e gaw a $\mathrm{M}$. Isolation of norbergenin from Saxifraga stolonifera. Phytochemistry. 1983; 22(4): 1053-1054. http://dx.doi.org/10.1016/0031-9422(83)85064-X

35. Goswami PK, Samant M, Srivastava RS. Multi faceted Saxifraga ligulata. Int J Res Ayurveda Pharm. 2013; 4(4): 608-611. http://dx.doi.org/10.7897/2277-4343. 04432

36. Chen Z, Liu YM, Yang S, Song BA, Xu GF, B hadury PS, et al. Studies on the chemical constituents and anticancer activity of Saxifraga stolonifera (L) Meeb. Bioorg Med Chem. 2008; 16(3): 1337-1344. http://dx.doi. org/10.1016/j.bmc.2007.10.072

37. K e v a n P G. Floral colors in the high arctic with reference to insect-flower relations and pollination. Can J Bot. 1972; 50(11): 2289-2316. http://dx.doi.org/10.1139/b72-298 
38. Kevan PG, Giurfa M, Chittka L. Why are there so many and so few white flowers? Trends Plant Sci. 1996; 1 : 280-284. http://dx.doi.org/10.1016/1360-1385(96)20008-1

39. Chittka L, Shmida A, Troje N, Menzel R. Ultraviolet as a component of flower reflections, and the colour perception of Hymenoptera. Vision Res. 1994; 34: 1489-1508. http://dx.doi.org/10.1016/0042-6989(94)901 $51-1$

40. Weigend M. Grossulariaceae. In: Flowering Plants. Eudicots. Berlin: Springer; 2007. p. 168-176.

\section{Mikromorfologia i anatomia kwiatów i nektarników skalnicy rozłogowej (Saxifraga stolonifera L.)}

Streszczenie

Skalnice to rośliny powszechnie występujące na wszystkich kontynentach. Wiele $\mathrm{z}$ nich przysto- sowanych jest do kwitnienia i reprodukcji w górzystych i kamienistych warunkach. Zapylane są przez różne grupy owadów i posiadają intrastaminal nektarniki kwiatowe. Morfo-anatomię kwiatów i nektarników Saxifraga stolonifera L. badano w mikroskopie świetlnym: jasnego pola i stereoskopowym oraz w skaningowym mikroskopie elektronowym. Odosiowa powierzchnia działek kielicha wyposażona jest w wielokomórkowe włoski gruczołowe zawierające antocyjany w komórkach podstawy i polifenole w komórkach wydzielniczych główki, natomiast na płatkach korony występują atraktanty sygnalizacyjne w postaci wskaźników barwnych. Gruczoł nektarnikowy osadzony jest na szczycie zalążni słupka w postaci mięsistej, żółto-pomarańczowej półkorony. Sekrecja nektaru odbywa się przez liczne, zmodyfikowane aparaty szparkowe. Parenchyma gruczołowa nie jest wyposażona $\mathrm{w}$ elementy tkanki przewodzącej. Ponadto w komórkach nektarnika zaobserwowano polifenole o pomarańczowo-brązowej barwie.

Handling Editor: Elżbieta Weryszko-Chmielewska

This is an Open Access digital version of the article distributed under the terms of the Creative Commons Attribution 3.0 License (creativecommons.org/licenses/by/3.0/), which permits redistribution, commercial and non-commercial, provided that the article is properly cited. 